\title{
Total mechanical stapled oesophagogastric anastomosis on the neck in oesophageal cancer - prevention of postoperative mediastinal complications
}

\author{
Jacek Zieliński ${ }^{1}$, Radosław Jaworski ${ }^{2}$, Ninela Irga-Jaworska ${ }^{3}$, Ireneusz Haponiuk ${ }^{2,4}$, Janusz Jaśkiewicz ${ }^{1}$ \\ ${ }^{1}$ Department of Oncological Surgery, Medical University of Gdansk, Poland \\ ${ }^{2}$ Department of Paediatric Cardiac Surgery, Mikołaj Kopernik Hospital in Gdansk, Poland \\ ${ }^{3}$ Department of Paediatrics, Haematology, and Oncology, Medical University of Gdansk, Poland \\ ${ }^{4}$ Chair of Physiotherapy, Gdansk University of Physical Education and Sport, Poland \\ Kardiochirurgia i Torakochirurgia Polska 2015; 12 (4): 318-321
}

\begin{abstract}
Oesophagogastric anastomosis after oesophagus resection is commonly performed on the neck. Even though a few different techniques of oesophagogastric anastomosis have been previously detailed, both manual and mechanical procedures have been burdened with leakages and strictures. Our simple technique of oesophagogastric anastomosis is a modification of mechanical anastomosis with the use of a circular stapler in order to prevent postoperative leak and concomitant mediastinal complications.

Since 2008, we have performed nine oesophagogastric anastomoses following oesophagus resection. The mean age of the operated patients was 54 years. There was no mortality among the operated patients in the early post-operative period. The mean follow-up period for the patients operated on in our department was 17 months until the time of the analysis. None of the patients showed any leakage or stricture, and no mediastinal complications were reported in the group.

Following our own experience, mechanical anastomosis with the use of a circular stapler seems to decrease the time of the operation as well as significantly reducing the incidence of leakages from the anastomosis. This type of anastomosis may decrease the number of postoperative strictures and the most dangerous mediastinal infections.

Key words: oesophagus cancer, surgical treatment, oesophagogastric anastomosis, mechanical anastomosis, mediastinal infections.
\end{abstract}

\section{Introduction}

Surgical treatment is the method of choice for oesophagus cancer. Restoration of the digestive tract is usually achieved with the use of the stomach, and less frequently with a part of the large intestine. Anastomosis with the

\section{Streszczenie}

Zespolenie przełykowo-żołądkowe po resekcji przełyku często wykonuje się na szyi. Choć opisano dotychczas kilka różnych technik wytwarzania zespolenia przełykowo-żołądkowego, zarówno zabiegi ręczne, jak i mechaniczne obciążone są ryzykiem przecieku i zwężenia. Przedstawiona przez autorów prosta technika zespolenia przełykowo-żołądkowego jest modyfikacją zespolenia mechanicznego z wykorzystaniem staplera okrężnego w celu zapobieżenia pooperacyjnym przeciekom i towarzyszącym powikłaniom śródpiersia.

Od 2008 r. autorzy wykonali 9 zespoleń przełykowo-żołądkowych po resekcjach przełyku. Średni wiek operowanych pacjentów wyniósł 54 lata. We wczesnym okresie pooperacyjnym nie odnotowano żadnego zgonu wśród operowanych pacjentów. Średni czas obserwacji pacjentów operowanych na oddziale do momentu analizy wyniósł 17 miesięcy. W analizowanej grupie nie odnotowano przecieków, zwężeń ani powikłań śródpiersia. Według doświadczenia autorów zespolenie mechaniczne przy użyciu staplera okrężnego wydaje się skracać czas zabiegu oraz istotnie zmniejsza występowanie przecieków z zespolenia. Opisywany typ zespolenia może zmniejszać liczbę zwężeń pooperacyjnych oraz najbardziej niebezpiecznych infekcji śródpiersia.

Słowa kluczowe: rak przełyku, leczenie chirurgiczne, zespolenie przełykowo-żołądkowe, zespolenie mechaniczne, infekcje śródpiersia.

stomach or large intestine is performed on the neck [1, 2]. Such a position of the anastomosis provides greater clinical control of the anastomosis and fewer side effects in case of leakage [1, 3]. The basic factor influencing the quality of anastomosis is the applied technique [4-6]. The most dan-

Address for correspondence: dr hab. n. med. Jacek Zieliński, Department of Oncological Surgery, Medical University of Gdansk, 17 Smoluchowskiego St., 80-214 Gdansk, phone: +48 5834931 90, fax: +48 5853011 05, e-mail: jaziel@gumed.edu.pl 
gerous early complication is perforation of the anastomosis with local infection, while various grade constrictions belong to late complications of every oesophagogastric anastomosis. Local complications are reported mostly after traditional, manually performed anastomoses [1]. Therefore, there is a search for new surgical techniques that would decrease the number of early and late complications in oesophageal surgery.

In the presented series of patients with oesophagus cancer nine resections with total mechanical stapled oesophagogastric anastomoses were performed. We present the technique and the analysis of the results in mid-time follow-up observation, with a focus on surgical technique and postoperative complications.

\section{Material and methods \\ Surgical technique}

The surgical procedure is carried out under general anaesthesia with the patient in a supine position, with concomitant access to the left-hand side of the neck. The liver, peritoneum, and perigastric lymph nodes are inspected after laparotomy for metastases as the first step. After confirming no dissemination of the cancer within the abdominal cavity, the stomach is evaluated for its usefulness as a graft for an anastomosis with the oesophagus on the neck. Stomach skeletonisation is performed in the typical way with preservation of the blood supply from the right gastro-omental artery (Fig. 1). In order to get more stomach mobility, the duodenum is mobilised using Kocher's method. After skeletonisation the stomach is cut off from the oesophagus, and the cardium and part of the lesser curvature together with lymph nodes are detached with the use of a linear stapler (TA 90, Covidien, USA). After stomach graft preparation, the cervical part of this procedure begins with an incision along the medial border of the left sternocleidomastoid muscle. Upon visualisation of the oesophagus on the neck, it is cut off at the point where it enters the thorax. The oesophagus stump in the thorax is closed with a knot suture, and a purse-string suture is placed on the stump on the neck.

The stomach graft is positioned retrosternally in the left supraclavicular area. Before starting the anastomosis,
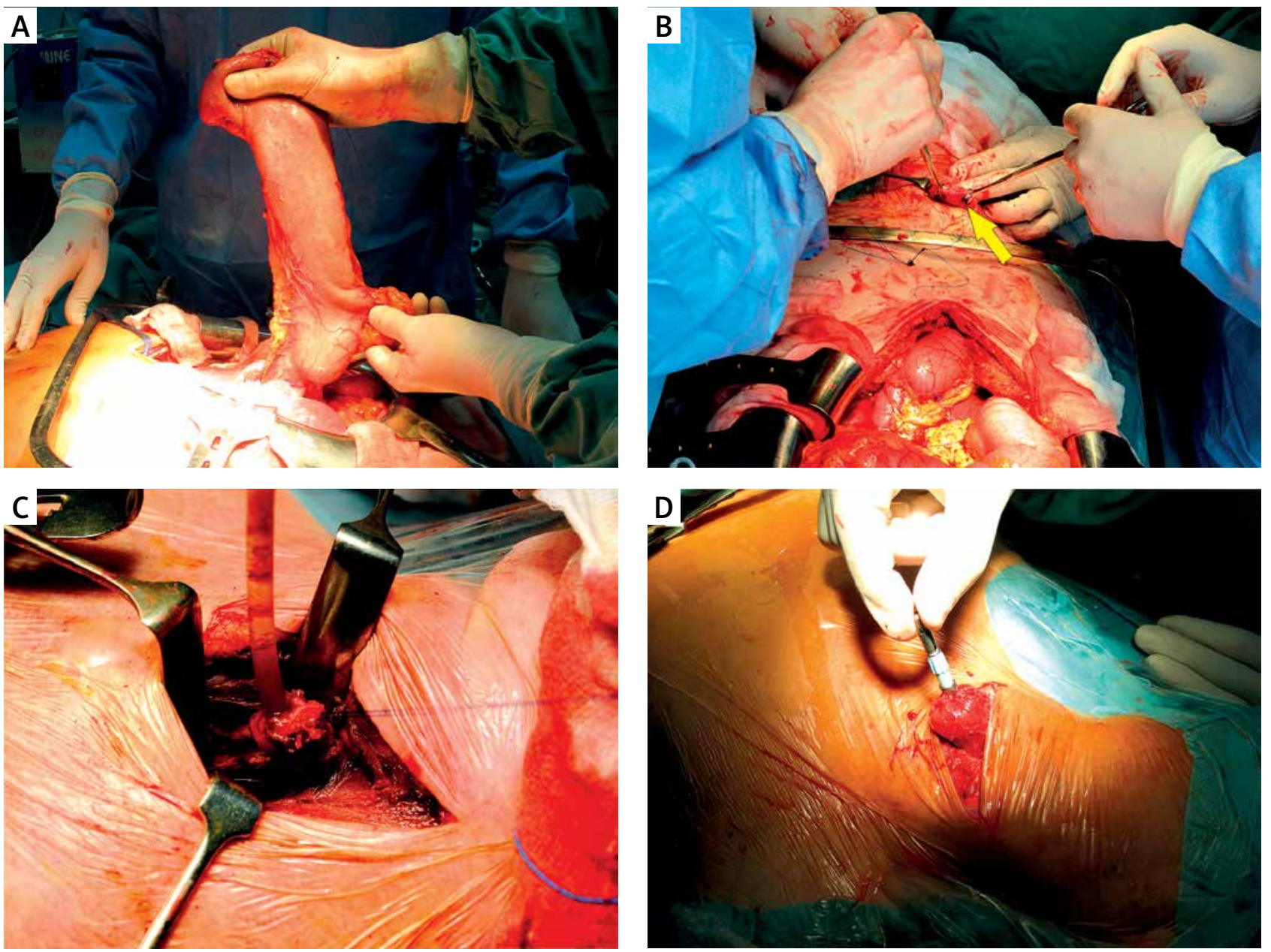

Fig. 1. Preparation of the stomach (A, B) and oesophagus on the neck $(C, D)$ in order to perform oesophagogastric anastomosis after oesophagus resection for oesophagus cancer: A) Stomach after skeletonisation, B) stomach displaced retrosternally on the neck (yellow arrow), C) oesophagus on the neck prepared for anastomosis (probe in the lumen of the oesophagus), D) oesophagus after stapler head placement (cervical oesophagus stump) 
the size of the oesophagus lumen is measured in order to choose the best diameter of the circular stapler (EEA 21 or 25, Covidien, USA). Circular staplers of $21 \mathrm{~mm}$ or $25 \mathrm{~mm}$ in diameter are most commonly used. The head of the stapler is placed in the oesophagus stump, whereupon an incision is made on the front wall of the fundus of the stomach in order to introduce the other part of the stapler. The end of the oesophagus is anastomosed with the posterior wall of the stomach in an 'end-to-side' fashion (Fig. 2). The anterior wall of the fundus of the stomach is closed with a linear stapler (TA 50, Covidien, USA). The procedure is significantly less time-consuming when compared to a classic manual anastomosis.

Tightness tests are carried out on the sixth postoperative day with serial $\mathrm{X}$-rays of the anastomosis after oral administration of contrast medium. The postoperative rehabilitation is administered in a routine fashion.

\section{Study protocol}

Retrospective analysis of the patients operated on with the use of the method described above was carried out.
All nine patients presented in the series were operated in the same surgical team, and they had given their informed free consent for this study. All nine patients were included in postoperative follow-up in an outpatient clinic. Clinical controls after oesophagus resection were planned every three months. Anonymous data were collected according to the scheduled protocol of the analysis. The exclusion criteria were the combined manual/mechanical technique, dissemination of the neoplasm after the surgery, generalised infection, and the lack of free consent of the patient for data collection.

\section{Local Ethics Committee approval}

The protocol of the study was approved by Local Ethics Committee for Human Research, Medical University of Gdansk (approval code number: 121/2011).

\section{Results}

In our department nine oesophagus resections with total mechanical stapled oesophagogastric anastomoses were performed in the period of the study between 2008
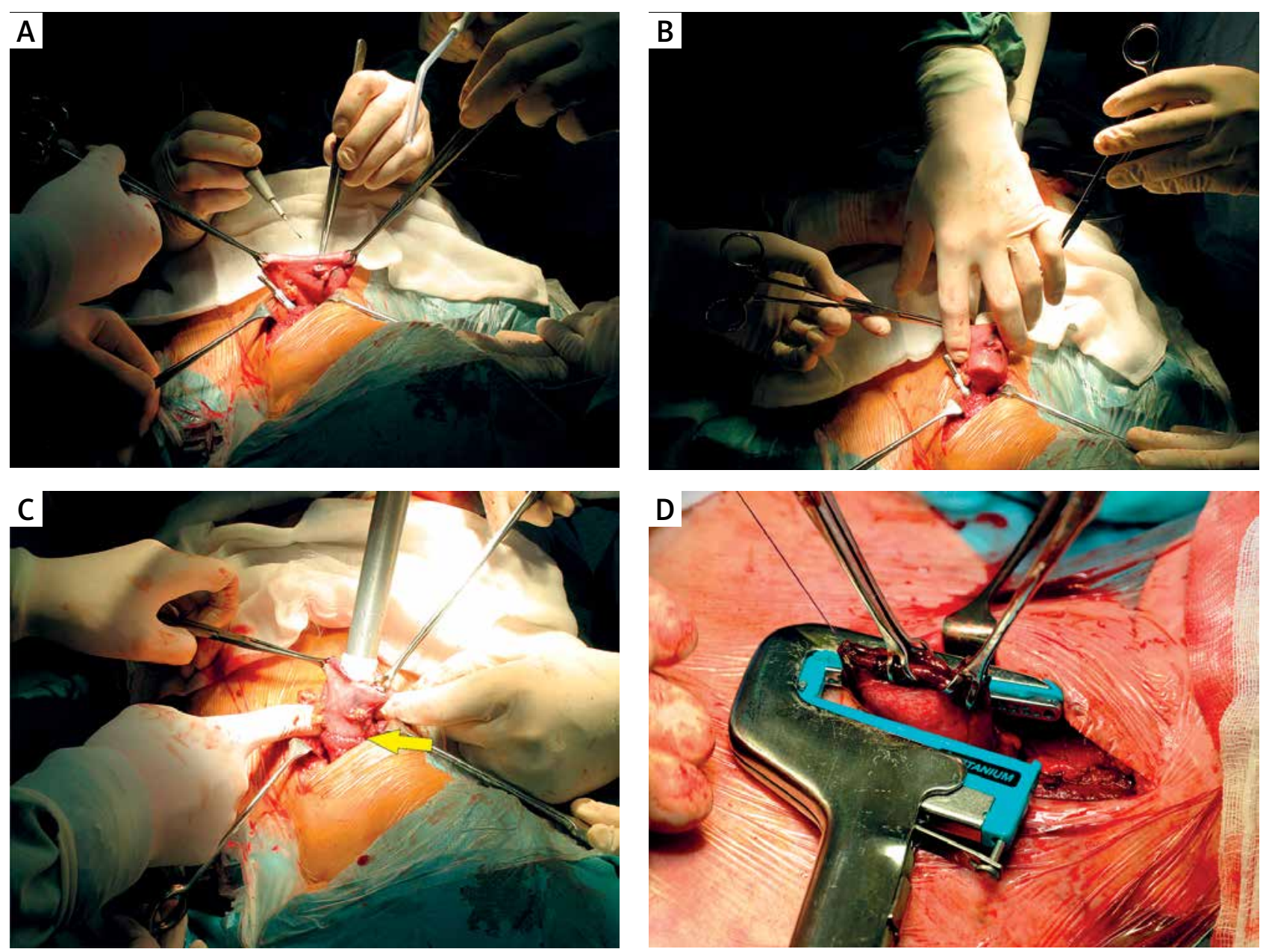

Fig. 2. Oesophagogastric anastomosis on the neck with the use of a circular stapler after oesophagus resection for oesophagus cancer (A-D): A) fundus of the stomach and oesophagus stump ready for anastomosis, B) incision of the anterior gastric wall and introduction of the stapler, C) oesophagogastric 'end-to-side' anastomosis (yellow arrow), D) closure of the fundus of the stomach with the use of a linear stapler 
and 2010. The mean age of the operated patients was 54 years (range: 24-60 years). In six cases a stapler of $21 \mathrm{~mm}$ in diameter was used, and in the other three cases a stapler of $25 \mathrm{~mm}$ in diameter.

No deaths were reported in the postoperative period (mortality $=0$ ). The mean follow-up period for the patients operated on in the Institution was 17 months (range: 7-34 months).

There were no local perforations of the mechanical anastomoses. No return surgeries needed to be performed in the group. All nine patients returned to modified oral feeding after the operation with recommended diet. There were no mediastinal infections in the site of the operation. None of the patients operated on with the use of mechanical staplers complained of symptoms related to local constriction, and there was no need for mechanical dilatation of the oesophageal anastomosis. There were no mediastinal local infections or generalised mediastinitis.

\section{Discussion}

The success of oesophagus resection in its thoracic part is related to essential elements of the procedure that are safe oesophagogastric anastomosis, with the prevention of local complication potentially related to every surgical technique. Relatively large numbers of leakages (10-23\%) and strictures (35\%) reported after manual oesophagogastric anastomoses on the neck have led to a search for new methods of anastomosing [1, 7-9].

The first reports on lower numbers of complications after oesophagogastric anastomoses carried out in a mechanical or combined mechanical/manual way versus manual-only techniques became available in the 1990s $[1,10]$. In 1998 Collard et al., and then in 2000 Orringer et al. described independently their techniques of oesophagogastric anastomoses in which a side-to-side anastomosis was performed with the manual closure of the site where the stapler was introduced. However, after this type of anastomosis, $35 \%$ of strictures required mechanical dilatation, and leakages were reported in $2.7 \%$ of cases $[1,10]$.

The optimal technique of oesophagogastric anastomosis had not yet been definitely established. The aim of our case-series analysis was to determine whether total mechanical oesophagogastric anastomosis in patients suffering from oesophageal cancer, after tumour resection, would provide an effective anastomosis and prevention from the most dangerous complications.

The value of the presented technique should be emphasised because the anastomosis between the cervical stump of the oesophagus and the posterior gastric wall creates a valvular mechanism preventing gastro-oesophageal refluxes. The fact that the remaining part of the stomach lies over the anastomosis is an additional benefit and may prevent local leakages. The use of mechanical staplers, de- spite the shortening of the procedure, provides additional benefits observed in the case series: fewer local complications and diminished risk of mediastinal infections.

\section{Conclusions}

The technique of mechanical oesophagogastric endto-side anastomoses with the use of a circular stapler apparently decreases the number of leakages or strictures in comparison to manual or combined manual/mechanical techniques. Mechanical anastomoses as in the described case-series seem to improve the effectiveness of surgical treatment and prevent the most frequent dangerous local complications.

\section{Acknowledgements}

The authors wish to thank Filip Stoma for his help in the final language form of the manuscript, and Raymond Malgeri, MA English, for his assistance with editing and revising the English translation of this manuscript.

\section{Disclosure}

Authors report no conflict of interest.

\section{References}

1. Orringer MB, Marshall B, lannettoni MD. Eliminating the cervical esophagogastric anastomotic leak with a side-to-side stapled anastomosis. J Thorac Cardiovasc Surg 2000; 119: 277-287.

2. Nederlof N, Tilanus HW, Tran TCK, Hop WCJ, Wijnhoven BPL, de Jonge J. Endto-End Versus End-to-Side Esophagogastrostomy After Esophageal Cancer Resection A Prospective Randomized Study. Ann Surg 2011; 254: 226-233.

3. Martin LW, Hofstetter W, Swisher SG, Roth JA. Management of intrathoracic leaks following esophagectomy. Advances Surg 2006; 40: 173-190.

4. Xu QR, Wang KN, Wang WP, Zhang K, Chen LQ. Linear stapled esophagogastrostomy is more effective than hand-sewn or circular stapler in prevention of anastomotic stricture: a comparative clinical study. J Gastrointestinal Surg 2011; 15: 915-921.

5. Yendamuri S, Gutierrez L, Oni A, Mashtare T, Khushalani N, Yang G, Nava H, Demmy T, Nwogu C. Does circular stapled esophagogastric anastomotic size affect the incidence of postoperative strictures? J Surg Res 2011; 165: 1-4.

6. Hsu HH, Chen JS, Huang PM, Lee JM, Lee YC. Comparison of manual and mechanical cervical esophagogastric anastomosis after esophageal resection for squamous cell carcinoma: a prospective randomized controlled trial. Eur J Cardiothoracic Surg 2004; 25: 1097-1101.

7. Singh D, Maley RH, Santucci T, Macherey RS, Bartley S, Weyant RJ, Landreneau RJ. Experience and technique of stapled mechanical cervical esophagogastric anastomosis. Ann Thorac Surg 2001; 71: 419-424.

8. Biere SS, Maas KW, Cuesta MA, van der Peet. Cervical or thoracic anastomosis after esophagectomy for cancer: a systematic review and metaanalysis. Dig Surg 2011, 28: 29-35.

9. Zieliński J, Świerblewski M, Kruszewski W J, Jaworski R, Haponiuk I, Irga N, Kopacz A, Jaśkiewicz J. Doświadczenia jednego ośrodka klinicznego w chirurgicznym leczeniu raka płaskonabłonkowego przełyku w latach 1970-2007. Kardiochir Torakochir Pol 2011; 8: 71-76.

10. Collard JM, Romagnoli R, Goncette L, Otte JB, Kestens PJ. Terminalized semimechanical side-to-side suture technique for cervical esophagogastrostomy. Ann Thorac Surg 1998; 65: 814-817. 